Roberts, E. C. \& Snell, E. E. (1946). F. biol. Chem. 163, 499.

Rosen, F., Huff, J. W. \& Perlzweig, W. A. (1946). F. biol. Chem. 163, 343.

Snell, E. E. \& Rannefeld, A. N. (1945). 7. biol. Chem. 157, 475.

Sreenivasan, A., Harper, A. E. \& Elvehjem, C. A. (1949). Y. biol. Chem. 177, 117.

Stokstad, E. L. R., Jukes, T. H., Pierce, J., Page, A. C. \& Franklin, A. L. (1949). F. biol. Chem. r8o, 647.

Teply, L. J. \& Elvehjem, C. A. (1945). F. biol. Chem. 157, 303.

\title{
The Importance to Sheep of Frequent Feeding
}

\author{
By J. G. GORDON AND D. E. TRIBE \\ Rowett Research Institute, Bucksburn, Aberdeenshire \\ (Received 4 Fuly 1951)
}

It has long been the practice of good stockmen to feed their animals 'a little and often'. This paper describes how this belief has been tested experimentally.

\section{EXPERIMENTAL}

Twenty-two Cheviot ewe hoggs were paired and divided into two equal groups which were comparable in age, body-weight and previous history. The sheep were penned singly, and to each was fed a daily ration consisting of $\mathrm{I}$ lb. chopped hay mixed with $\mathrm{I} \frac{1}{2} \mathrm{lb}$. of the following concentrate mixture: yellow maize meal 57 , crushed oats $I_{5}$, wheat bran 14 , linseed-cake meal 7 , and white fish meal $7 \%$.

In addition to these rations each animal was offered an $a d l i b$. supply of water and had access at all times to both plain salt and mineral licks. This quantity of food was maintained throughout the $\mathrm{I} 8$ weeks of the experiment as it was considered that to increase it with increasing body-weight would serve only to complicate the experiment.

During the first part of the experiment, which lasted for a period of 9 weeks, group A was fed eight times daily at approximately hourly intervals between the hours of 9.30 a.m. and 5.15 p.m. On each occasion one-eighth of the total ration was given, i.e. 3 oz. concentrates and 2 oz. chopped hay. Group B received its daily ration as one large feed at 9.15 a.m. For the second 9-week period the treatments were reversed, group B being given the frequent treatment and group A fed once daily. The animals were weighed twice weekly throughout the experiment. Food residues were weighed, no account being taken of their composition, and the total quantity of food eaten daily was recorded. Animals on a single feed rarely left a food residue, but, on the other hand, those fed frequently commonly did this as is shown in Table 2.

\section{RESULTS}

The criteria used in the interpretation of the results are those of body-weight gains and efficiencies of food utilization. The latter refer to net efficiencies and are calculated by dividing the starch equivalent (lb.) consumed over and above maintenance requirements during each 9 -week period by the body-weight gain (lb.) during that time. The results of the experiment are shown in terms of body-weight gains in 
Table I, and the body-weight changes for both groups are expressed graphically in Fig. I.

Table I. Frequent versus single feeding of sheep. Body-weight gains of all animals throughout the experiment

\begin{tabular}{|c|c|c|c|c|c|c|c|}
\hline \multicolumn{4}{|c|}{ Group A } & \multicolumn{4}{|c|}{ Group B } \\
\hline & \multicolumn{3}{|c|}{ Body-weight gain (lb.) } & & \multicolumn{3}{|c|}{ Body-weight gain (lb.) } \\
\hline $\begin{array}{c}\text { Sheep } \\
\text { no. }\end{array}$ & $\begin{array}{l}\text { Period I } \\
\text { (frequent } \\
\text { feeding) }\end{array}$ & $\begin{array}{c}\text { Period } 2 \\
\text { (single } \\
\text { feeding) }\end{array}$ & $\begin{array}{l}\text { Difference } \\
\text { due to } \\
\text { frequent } \\
\text { feeding }\end{array}$ & $\begin{array}{c}\text { Sheep } \\
\text { no. }\end{array}$ & $\begin{array}{c}\text { Period I } \\
\text { (single } \\
\text { feeding) }\end{array}$ & $\begin{array}{c}\text { Period } 2 \\
\text { (frequent } \\
\text { feeding) }\end{array}$ & $\begin{array}{l}\text { Difference } \\
\text { due to } \\
\text { frequent } \\
\text { feeding }\end{array}$ \\
\hline I & 7 & 4 & 3 & 16 & I & I3 & 12 \\
\hline 2 & 9 & 5 & 4 & 21 & 2 & 15 & I 3 \\
\hline 3 & 9 & $-I$ & 10 & 22 & -2 & 14 & 16 \\
\hline 4 & 15 & 5 & IO & 18 & 2 & 16 & 14 \\
\hline 5 & 7 & 3 & 4 & I 5 & $-r$ & 9 & I0 \\
\hline 6 & 17 & 4 & 13 & 14 & 7 & 12 & 5 \\
\hline 7 & 5 & $-I$ & 6 & 20 & 6 & 17 & I I \\
\hline 8 & 10 & 5 & 5 & 13 & I & 12 & II \\
\hline 9 & 4 & 6 & -2 & 17 & 3 & 14 & II \\
\hline 10 & 8 & 2 & 6 & 23 & I & 16 & I 5 \\
\hline I I & 5 & I & 4 & 24 & -2 & I3 & I5 \\
\hline & al 96 & 33 & 63 & & 18 & ${ }_{15} \mathrm{I}$ & I 33 \\
\hline
\end{tabular}

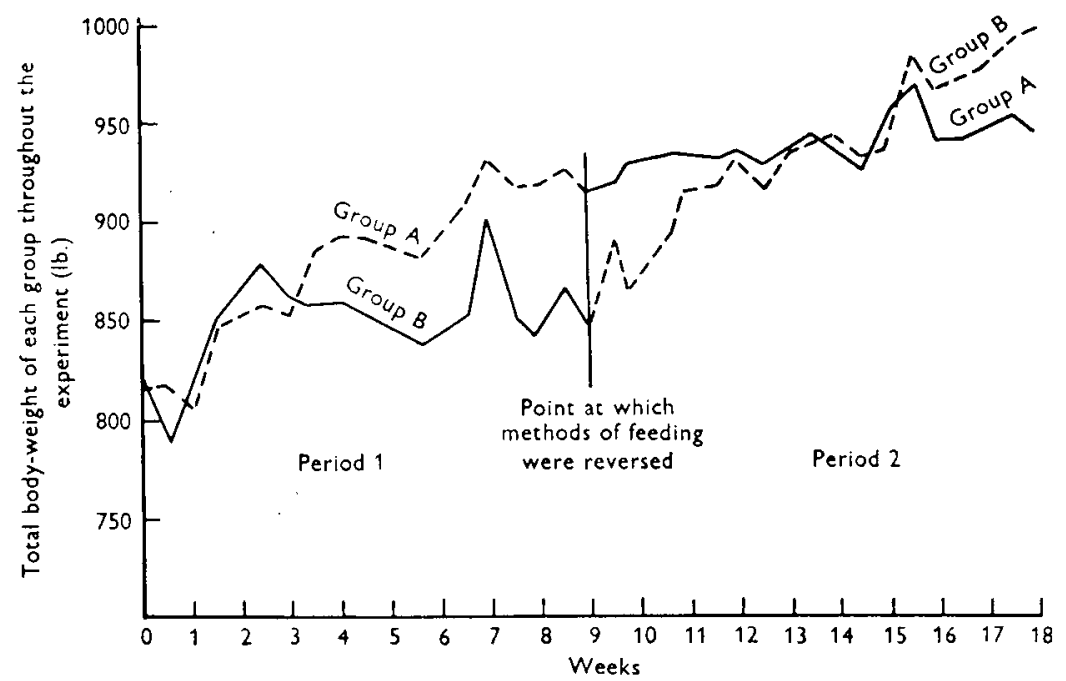

Fig. I. Frequent versus single feeding of sheep. Total body-weight of each group during both experimental periods. - - - , frequent feeds; - , single daily feeds.

During period I, group A, on frequent feeding, gave a total live-weight increase of $96 \mathrm{lb}$., whereas group $B$, on one feed daily, increased by only $18 \mathrm{lb}$. During period 2, group A, now fed only once each day, gave a total live-weight increase of $33 \mathrm{lb}$., whereas group $\mathrm{B}$, now fed frequently, gained $\mathrm{x}_{5} \mathrm{l} \mathrm{lb}$.

By subtracting the increase on single feeding from that on frequent feeding for each group the total increase due to frequent feeding is obtained. For group A this is 
$63 \mathrm{lb}$. and for group B $133 \mathrm{lb}$., a total of $196 \mathrm{lb}$. extra live-weight gain. This same total can also be arrived at by adding together the differences between the groups during the same periods. Statistical analysis has shown that these differences are highly significant $(P<0.001)$.

This experiment suggests that not only does frequent feeding increase the rate of live-weight increase but it also causes a depression of appetite. Tables $I$ and 2 show that in group A over the period of frequent feeding an average of $8.6 \mathrm{lb}$. of food was refused

Table 2. Frequent versus single feeding of sheep. Food residues and net efficiencies of food utilization for each animal throughout the experiment

(The net efficiencies are calculated by dividing the starch equivalent (lb.) consumed over and above maintenance requirements during each 9 -week period by the body-weight gain (lb.) during that time)

\begin{tabular}{|c|c|c|c|c|c|}
\hline \multirow[t]{2}{*}{ Group } & \multirow[t]{2}{*}{ Sheep no. } & $\begin{array}{c}\text { Food residue } \\
\text { (lb.) }\end{array}$ & $\begin{array}{l}\text { Efficiency of } \\
\text { food utilization }\end{array}$ & $\begin{array}{c}\text { Food residue } \\
\text { (lb.) }\end{array}$ & $\begin{array}{l}\text { Efficiency of } \\
\text { food utilization }\end{array}$ \\
\hline & & \multicolumn{2}{|c|}{ Period I (frequent feeding) } & \multicolumn{2}{|c|}{ Period 2 (single feeding) } \\
\hline \multirow[t]{12}{*}{$\mathbf{A}$} & I & $\circ$ & $6 \cdot 7$ & $1 \cdot 3$ & II'O \\
\hline & 2 & $1 \cdot 8$ & $5 \cdot 2$ & $2 \cdot 9$ & $9 \cdot 0$ \\
\hline & 3 & $5 \cdot 25$ & 47 & 0 & $\cdots$ \\
\hline & 4 & 10.5 & $3 \cdot 2$ & $4 \cdot 5$ & $9 \cdot 5$ \\
\hline & 5 & 6.75 & $6 \cdot 4$ & 0 & 14.9 \\
\hline & 6 & 0 & $2 \cdot 7$ & 0 & 10.5 \\
\hline & 7 & 0 & $8 \cdot 4$ & $\mathrm{I} \cdot 8$ & - \\
\hline & 8 & $4 \cdot 25$ & 4.4 & $I \cdot 2$ & $8 \cdot 5$ \\
\hline & $\begin{array}{r}9 \\
10\end{array}$ & $\begin{array}{r}59 \cdot 7 \\
6.0\end{array}$ & $\begin{array}{l}9.1 \\
5.6\end{array}$ & $\begin{array}{l}3.5 \\
0\end{array}$ & $\begin{array}{r}7 \cdot 4 \\
21 \cdot 8\end{array}$ \\
\hline & I I & 0 & $8 \cdot 6$ & 0 & $42 \cdot I$ \\
\hline & & Mean 8.57 & $5^{\circ} 9$ & $I \cdot 4$ & $15^{\circ} 0$ \\
\hline & & \multicolumn{2}{|c|}{ Period I (single feeding) } & \multicolumn{2}{|c|}{ Period 2 (frequent feeding) } \\
\hline \multirow[t]{12}{*}{ B } & 16 & 0 & $48 \cdot 0$ & 3.9 & 3.4 \\
\hline & 21 & 0 & 23.7 & $9 \cdot 8$ & $2 \cdot 7$ \\
\hline & 22 & o & - & $2 \cdot 6$ & $3 \cdot 1$ \\
\hline & 18 & 0 & $25^{\circ} 8$ & $7 \cdot 8$ & $2 \cdot 8$ \\
\hline & I5 & 0 & - & $2 \cdot 0$ & $4 \cdot 9$ \\
\hline & 14 & 0.7 & $6 \cdot 8$ & $3 \cdot 8$ & 3.6 \\
\hline & 20 & $8 \cdot 15$ & $7 \cdot 5$ & $I \cdot I$ & $2 \cdot 5$ \\
\hline & I 3 & 0 & $46 \cdot 2$ & $3 \cdot 8$ & $3 \cdot 6$ \\
\hline & I7 & 0 & $16 \cdot 0$ & $\mathbf{I} \cdot \mathbf{I}$ & $3 \cdot 8$ \\
\hline & 23 & 0 & $46 \cdot 2$ & $2 \cdot 2$ & $2 \cdot 7$ \\
\hline & 24 & 0 & - & $3 \cdot 1$ & $3 \cdot I$ \\
\hline & & Mean 0.84 & $27 \cdot 5$ & 3.7 & $3 \cdot 3$ \\
\hline
\end{tabular}

by each sheep, an average gain in body-weight of $9 \mathrm{lb}$. was made, and the average efficiency of utilization was $5 \cdot 9$. On single daily feeds in period 2 an average of only I.4 lb. of food was rejected and a gain of only $3 \mathrm{lb}$. was made. The efficiency of utilization was much inferior, namely I $^{\circ} \circ$. In group $B$ these figures are even more decisive. While frequently fed these animals gave an average efficiency quotient of 3.3 , but when fed only once each day this figure rose to 27.5 . While on frequent feeding all the animals involved consumed on an average $13.5 \mathrm{lb}$. of food for every $\mathrm{lb}$. of live-weight increase. On single feeding this was increased to the very high figure of $67.5 \mathrm{lb}$. of food per lb. of increase.

It is of interest to note a further comparison. The total body-weight of all the sheep 
involved at the start of the experiment was $1642 \mathrm{lb}$.; at the end they totalled $1940 \mathrm{lb}$. Thus a total gain of $298 \mathrm{lb}$. was made, of which $196 \mathrm{lb}$., or $65.8 \%$, were due to frequent feeding, an effect equivalent to the expected live weights of about two and a half sheep or the carcass weights of four or five sheep at the end of the same feeding period if frequent feeding had not been employed.

\section{DISCUSSION}

To what may these differences be attributed? Unfortunately it is only possible, at the moment, to offer a few suggestions with little or no experimental backing. Four possibilities will be discussed.

(I) It may be that when a ration is divided into several small feeds spread over a long period of time the total surface area open to attack by micro-organisms in the rumen might be larger and/or available for a longer time per unit of microbial activity than when the same quantity and quality of food is given as one meal. In this way a more efficient coefficient of digestibility might be obtained.

(2) The work of Schalk \& Amadon (1928) and Balch (1950) suggests that since food material passes into the omasum from the reticulum at a constant and not too rapid rate throughout the day, and since during a meal the heavier and more finely divided portion of the ration rapidly reaches the reticulum, then under a system of small feeds this portion will pass on and into the abomasum in a short period of time. Therefore the loss of energy due to fermentation processes will be minimal. However, if a large amount of food is ingested at one time it probably remains for longer in the rumino-reticular cavity, and this disproportionately greater delay will result in large energy losses.

(3) A completely different aspect is suggested by the third possibility. The even supply of substrate and the supposedly even production of metabolites that may occur under the frequent feed system may $(a)$ give rise to an alimentary environment better suited to the growth and metabolism of micro-organisms, and $(b)$ it may enable the animal to utilize the metabolites more efficiently than under the single feed system where there may be a more rapid flooding of the tissues than is compatible with an optimal rate of utilization.

(4) It is possible that the length of time spent ruminating by the animal under the two systems of management may be different and might, by the consequent differences in mechanical action upon the food, result in differences in digestibility. Continuous observations were made on the ruminating behaviour of four sheep, two from each group, over a $72 \mathrm{~h}$ period. The total time spent ruminating by the two frequently fed sheep was $2534 \mathrm{~min}$, whereas the two singly fed sheep spent 3483 min ruminating. Further work is continuing along these lines.

It will be noticed that these four possibilities assume that frequent feeding is only effective in giving increased body-weights in ruminants. It would be of interest to know whether such is the case with single-stomached animals.

In a pilot digestibility-trial, in which it was unfortunately only possible to use two sheep, one on each treatment, results of a ro-day experimental period, following a 9-week preliminary period, gave differences in the digestibility of nitrogen of the 
order of $10 \%$, and a nitrogen balance showed a retention of $52 \mathrm{~g}$ nitrogen in favour of the frequently fed animal.

It was considered that these results are sufficiently suggestive to warrant an expansion of this study. At the moment, however, we are content to conclude that an increased live-weight gain and an increased efficiency of food utilization are obtained when sheep are fed 'a little and often' and that the reasons for this are as yet not understood.

In conclusion two aspects of this study that may have some application in ( $\mathrm{I}$ ) research and (2) practical agriculture should be mentioned.

(I) In digestibility studies where cut herbage is fed to animals under laboratory conditions it would seem to be important that they should be given the herbage a little at a time instead of, as is the usual practice, in two feeds at the most. These findings, and the fact that grazing animals do eat 'a little and often' (Tribe, I949), would seem to indicate the necessity for this, although if our explanation, number (2) above, is the correct one, the effect obtained in this study under conditions of hay and concentrate feeding might not be reproducible when feeding herbage.

(2) It might be possible to apply this principle in the fattening of livestock. It should not be difficult to devise automatic methods for the frequent feeding of housed animals. The reduction in the amounts of food and time necessary for fattening and the consequent decrease in overhead costs would probably make this an economic proposition.

\section{SUMMARY}

I. Twenty-two Cheviot ewe hoggs gave greater body-weight gains and an increased efficiency of food utilization when offered their daily ration in eight small feeds than when given the same quantity and quality of food in one large feed.

2. The possible reasons for, and the possible applications of, these results are discussed.

We are indebted to $\mathrm{Mr} \mathrm{B}$. S. Walker for assistance in the management of the experimental animals, and to $\mathrm{Mr} \mathrm{J}$. L. Corbett for statistical advice.

\section{REFERENCES}

Balch, C. C. (1950). Brit. F. Nutrit. 4, 361.

Schalk, A. F. \& Amadon, R. S. (Ig28). Bull. N. Dak. agric. Exp. Sta. no. 216.

Tribe, D. E. (1949). Emp. F. exp. Agric. 17, 105. 